\title{
UPAYA MENINGKATKAN HASIL BELAJAR GERAK DASAR LOMPAT JAUH GAYA MENGGANTUNG DENGAN MENGGUNAKAN ALAT BANTU KOTAK KARDUS
}

\section{Martinus Handoko Prastowo}

Guru SDN Kanung 02 Kecamatan Sawahan Kabupaten Madiun Jawa Timur, Indonesia

Email: martinus.handoko@gmail.com

\section{Abstract}

The purpose of this research is to improve the achievements of long jump hanging style sports through the use of cardboard box aids, learning in grade VI students of SDN Kanung 02 sawahan subdistrict madiun in the 2019/2020 school year. This research uses Class Action Research (PTK) method. The data analysis techniques used are descriptive quantitative. The research procedure is to determine the steps in carrying out the research. The steps of implementation of PTK procedurally is carried out participatory or collaboration (teachers, other PJOK) in collaboration, starting from the orientation stage followed by the preparation of action plans followed by the implementation of actions in cycle I, analytical discussions that are then continued to the reflection-evaluative steps of activities carried out in cycle I, to then prepare a plan of modification, correction, or correction, or improvement in cycle II and so on. The results showed that by using learning aids can improve the results of learning basic motion long jump style hanging from pre cycle to cycle I and from cycle I to cycle II. The result of long jump learning style hanging on pre cycle in the complete category is $33.3 \%$ or 6 students, at the end of cycle I after being given learning basic motion techniques long jump hanging style using cardboard aids increased to $55.55 \%$ or 10 students, then again there was an increase after being given action in cycle II to $88.88 \%$ or 16 students with more emphasis on increasing the chances of students in doing the long jump movement overall. The conclusion of this study is that the use of learning aids can improve the results of learning the basic motion of long jump hanging style in grade VI students of SDN Kanung 02 in the 2019/2020 school year.

Keywords: learningaids; long jump hanging style; Education

\section{Abstrak}

Tujuan penelitian ini adalah untuk meningkatkan prestasi cabang olahraga lompat jauh gaya menggantung melalui penggunaan alat bantu kotak kardus, pembelajaran pada siswa kelas VI SDN Kanung 02 kecamatan Sawahan kabupaten Madiun tahun pelajaran 2019/2020. Penelitian ini menggunakan metode Penelitian Tindakan Kelas (PTK). Teknik analisis data yang digunakan adalah deskriptif kuantitatif. Prosedur penelitian adalah dengan menentukan langkah-langkah dalam melaksanakan penelitian. Adapun langkah-langkah pelaksanaan PTK secara prosedurnya adalah dilaksanakan secara partisipatif atau kolaborasi (guru, PJOK lainnya) bekerjasama, mulai dari tahap orientasi dilanjutkan penyusunan rencana tindakan dilanjutkan pelaksanaan tindakan dalam siklus I, diskusi yang bersifat 
analitik yang kemudian dilanjutkan kepada langkah refleksi-evaluatif atas kegiatan yang dilakukan pada siklus I, untuk kemudian mempersiapkan rencana modifikasi, koreksi, atau pembetulan, atau penyempurnaan pada siklus II dan seterusnya. Hasil penelitian menunjukkan bahwa dengan menggunakan alat bantu pembelajaran dapat meningkatkan hasil belajar gerak dasar lompat jauh gaya menggantung dari pra siklus ke siklus I dan dari siklus I ke siklus II. Hasil belajar lompat jauh gaya menggantung pada pra siklus dalam kategori tuntas adalah 33,3\% atau 6 siswa, pada akhir siklus I setelah diberikan pembelajaran teknik gerak dasar lompat jauh gaya menggantung menggunakan alat bantu kardus meningkat menjadi 55,55\% atau 10 siswa, kemudian kembali terjadi peningkatan setelah diberikan tindakan pada siklus II menjadi $88,88 \%$ atau 16 siswa dengan lebih menekankan memperbanyak kesempatan siswa dalam melakukan gerakan lompat jauh secara keseluruhan. Simpulan penelitian ini adalah penggunakan alat bantu pembelajaran dapat meningkatkan hasil belajar gerak dasar lompat jauh gaya menggantung pada siswa kelas VI SDN Kanung 02 tahun pelajaran 2019/2020.

Kata kunci: alat bantu pembelajaran; lompat jauh gaya menggantung; pendidikan

Coresponden Author

Email: martinus.handoko@gmail.com Artikel dengan akses terbuka dibawah lisensi

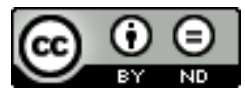

\section{Pendahuluan}

Pendidikan di Indonesia merupakan salah satu masalah yang menjadi sorotan dari berbagai pihak baik dari masyarakat, departemen pendidikan dan kebudayaan maupun departemen lainnya (Wahidin, 2017). Pengembangan aspek jasmani anak dapat ditunjang melalui beberapa kegiatan antara lain melalui kegiatan olahraga. Melalui olahraga akan dapat ditingkatkan kekuatan ketrampilan kerja, kesegaran jasmani, dan pembentukan kepribadian yang baik. Hal ini berarti bahwa peranan olahraga sangat penting artinya dalam menunjang kehidupan manusia agar tetap sehat dan memiliki kesegaran jasmani yang prima sehingga dapat melaksanakan tugas sehari-hari dengan baik (Utama, 2011).

Olahraga merupakan kegiatan fisik yang bersifat kompetitif dalam suatu permainan, berupa perjuangan tim maupun diri sendiri (Lestari, Indarwati, \& Putra, 2018). Salah satu olahraga yang berbentuk kompetitif tersebut adalah atletik. Atletik merupakan salah satu cabang olahraga yang tertua yang telah ada dan dilakukan oleh manusia sejak jaman dahulu sampai sekarang ini. Bahkan dapat dikatakan sejak adanya manusia di muka bumi ini, atletik sudah ada dan dilakukan oleh manusia. Hal tersebut dikarenakan setiap gerakan dalam atletik seperti jalan, lari, lompat dan lempar merupakan perwujudan dari gerakan dasar dalam kehidupan manusia sehari-hari (Refiater, 2012).

Atletik merupakan induk dari semua cabang olahraga yang diajarkan dari sekolah tingkat paling rendah Sekolah Dasar sampai dengan Perguruan Tinggi, Cabang olahraga 
atletik didalamnya terdiri empat nomor utama yaitu jalan, lari, lompat dan lempar. Dari tiap-tiap nomor tersebut didalamnya terdapat beberapa nomor yang diperlombakan. Untuk nomor lari terdiri atas: lari jarak pendek, jarak menengah, jarak jauh, lari gawang, lari sambung atau lari estafet. Nomor lompat meliputi: lompat jauh, lompat tinggi, lompat jangkit, lompat tinggi galah. Nomor lempar meliputi: lempar cakram, lempar lembing, tolak peluru dan lontar martil (Indra, 2018).

Berkaitan dengan nomor-nomor atletik, penelitian ini akan mengkaji dan meneliti nomor lompat khususnya lompat jauh gaya menggantung. Lompat jauh gaya menggantung merupakan rangkaian gerakan yang diawali dengan berlari, menumpu untuk menolak, melayang di udara dengan posisi badan tegap dan mendarat dengan kedua kaki ke depan. Lompat jauh gaya menggantung merupakan gaya yang sering dilakukan atlit yg berprestasi. (Aip Syarifudin, 1992) menyatakan bahwa, "lompat jauh gaya menggantung, pada umumnya banyak dilakukan anak-anak sekolah, karena dianggap gaya yang paling mudah untuk dipelajari”. Hal ini disebabkan karena lompat jauh gaya menggantung tidak banyak gerakan yang harus dilakukan pada saat melayang di udara dibandingkan dengan gaya yang lainnya. Dikatakan gaya menggantung karena gerakan yang dilakukan pada saat melayang badan melenting di udara atau membentuk gerakan seperti lentingan di udara.

Pada dasarnya pendidikan jasmani merupakan bagian integral dari sistem pendidikan secara keseluruhan, bertujuan untuk mengembangkan aspek kesehatan, kebugaran jasmani, keterampilan berfikir kritis, stabilitas emosional, keterampilan sosial, penalaran dan tindakan moral melalui aktivitas jasmani dan olahraga. Peranan Pendidikan Jasmani adalah sangat penting, yang memberikan kesempatan kepada siswa untuk terlibat langsung dalam aneka pengalaman belajar melalui aktivitas jasmani, bermain dan olahraga yang dilakukan secara sistematis (Irianto, 2020).

Adapun tujuan pendidikan jasmani menurut (Suherman, 2000) bahwa, "Secara umum tujuan pendidikan jasmani dapat diklasifikasikan kedalam empat kategori yaitu : (1) perkembangan fisik, (2) perkembangan gerak, (3) perkembangan mental dan, (4) perkembangan sosial".

Salah satu masalah utama dalam pendidikan jasmani di Indonesia hingga sekarang ini adalah belum efektifnya pengajaran pendidikan jasmani di sekolah-sekolah, kondisi seperti ini dikarenakan rendahnya kualitas pembelajaran yang terjadi (Rachman, 2011). Hal ini disebabkan oleh beberapa faktor, diantaranya ialah terbatasnya kemampuan guru pendidikan jasmani dan terbatasnya sumber-sumber yang digunakan untuk mendukung pengajaran proses pendidikan jasmani. Sebagian besar guru PJOK (Pendidikan, jasmani, olahraga, kesehatan) yang ada sekarang ini hanya menekankan hasil akhir tanpa memperhatikan proses pembelajaran, hal ini akan berdampak buruk bagi siswa karena kurangnya pengetahuan yang diberikan oleh guru dan secara tidak langsung akan mempengaruhi kinerja guru tersebut serta tujuan pendidikan jasmani yang tidak tercapai.

Pembelajaran PJOK (Pendidikan, jasmani, olahraga, kesehatan) melalui penggunaan alat bantu pembelajaran merupakan salah satu karakteristik model 
pembelajaran yang dapat diterapkan dalam pembelajaran penjas (Bajuri, 2016). Adanya model pembelajaran dengan alat bantu dapat membantu seorang guru menciptakan suasana pembelajaran yang lebih baik sehingga motivasi siswa meningkat. Kemampuan seorang guru membangkitkan motivasi belajar siswa menjadi salah satu kunci tercapainya tujuan pembelajaran. (Srijono Brotosuryo, 1994) menyatakan, "Dalam proses belajar mengajar sarana dan alat bantu mengajar merupakan komponen yang tidak dapat dipisahkan dengan komponen-komponen lain, misalnya: tujuan, materi, metode dan sebagainya". Oleh karena itu guru PJOK yang profesional sangat menentukan keberhasilan dalam proses pembelajaran dan pendidikan. Proses pembelajaran harus dikelola dengan baik agar mencapai keberhasilan yang baik pula. Salah satu pendukung keberhasilan dalam pembelajaran adalah penggunakan alat media dalam menyampaikan pembelajaran. Alat media adalah alat bantu pembelajaran yang dapat mengaktifkan siswa dan guru dalam proses pembelajaran sehingga dapat merangsang pikiran, perasaan, perhatian dan kemampuan berfikir siswa sehingga pengalaman belajar yang diperoleh lebih bermanfaat. Untuk menerapkan pembelajaran yang bisa memotivasi anak dan diharapkan dapat meningkatkan hasil belajar lompat jauh gaya jongkok maka, muncul gagasan untuk melakukan penelitian dengan judul "Upaya meningkatan hasil belajar gerak dasar lompat jauh gaya menggantung dengan menggunakan alat bantu tradisional pada siswa Kelas VI SDN Kanung 02 kecamatan Sawahan kabupaten Madiun tahun pelajaran 2019/2020”.

Dari hasil penelitian terdahulu yang relevan ada beberapa kajian yang sangat diperlukan untuk mendasari penelitian-penelitian selanjutnya Penelitian Muchlis (Choirudin, 2012) menyatakan bahwa ada 4 tahapan yang harus dikuasai dalam melakukan lompat jauh gaya jongkok supaya mendapatkan prestasi yang optimal yaitu awalan, tumpuan, melayang diudara dan mendarat.

\section{Metode Penelitian}

1. Tempat dan Waktu Penelitian

Penelitian Tindakan Kelas ini dilaksanakan di lapangan Lompat jauh SDN Kanung 02 kecamatan Sawahan kabupaten Madiun. Penelitian ini direncanakan mulai bulan November s/d Desamber 2019 setiap berlangsungnya mata pelajaran Pendidikan Jasmani siswa Kelas VI SDN Kanung 02 Kecamatan Sawahan Kabupaten Madiun Tahun Pelajaran 2019/2020, yaitu setiap hari Kamis dari pukul 07.00 sampai 08.45 WIB. Hal ini dilakukan karena dalam penelitian tindakan kelas proses pelaksanaan penelitian tidak boleh menggangu proses belajar mengajar itu sendiri.

2. Subjek Penelitian

Subjek dalam penelitian ini siswa kelas VI SDN Kanung 02 Kecamatan Sawahan kabupaten Madiun tahun Pelajaran 2019/2020. Jumlah keseluruhan siswa adalah sebanyak 18 siswa yang terdiri dari 10 siswa putra dan 8 putri. Seluruh siswa diamati untuk mengetahui tingkat perkembangan hasil belajar. 
3. Data dan Sumber Data

Data yang digunakan dalam penelitian ini adalah sebagai berikut:

1. Data Primer, berupa RPP, hasil belajar dan proses pembelajaran penjas di SDN Kanung 02 kecamatan sawahan

2. Data Sekunder, berupa, silabus dan dokumen siswa Kelas VI SDN Kanung 02 kecamatan Sawahan

4. Pengumpulan Data

Data yang dikumpulkan dalam penelitian ini meliputi informasi tentang keadaan siswa dilihat dari aspek kualitatif, dan kuantitatif. Aspek kualitatif berupa catatan lapangan pelaksanaan pembelajaran, hasil observasi dengan berpedoman pada lembar observasi. Aspek kuantitatif yang dimaksud adalah hasil penilaian belajar dari materi pokok Lompat jauh gaya jongkok. Data penelitian dikumpulkan dari berbagai sumber meliputi:

a. Observasi

b. Wawancara

c. Dokumentasi atau arsip yang antara lain berupa kurikulum, sekenario pembelajaran, silabus buku penilaian dan buku referensi mengajar.

5. Uji Validitas Data

Untuk menjamin validitas data dan pertanggung jawaban yang dapat dijadikan dasar yang kuat untuk menarik kesimpulan, maka yang digunakan untuk memeriksa validitas data yaitu dengan validitas isi dan teknik trianggulasi.

Validitas isi mencakup sejauh mana bentuk tes yang digunakan dalam penelitian ini sudah sesuaikah dengan silabus mata pelajaran PJOK kelas VI yang dikonsultasikan dengan observer. Sedangkan teknik triangulasi yang digunakan yang sebagai validasi keaktifan atau aktivitas siswa dan guru selama proses pembelajaran adalah triangulasi metode, yaitu dengan cara :

1. Data aktivitas siswa selama proses pembelajaran diperoleh dengan observasi lalu dicek dengan dokumentasi yang meliputi hasil kerja siswa, lembar observasi aktivitas siswa dan foto proses pembelajaran. Apabila dengan teknik pengujian tersebut dihasilkan data yang sama, maka data tersebut dinyatakan valid.

2. Data aktivitas guru selama proses pembelajaran diperoleh dengan observasi lalu dicek dengan dokumentasi yang meliputi lembar observasi kinerja guru, foto proses pembelajaran. Apabila melalui pengujian tersebut dihasilkan data yang sama maka data tersebut dinyatakan valid.

6. Analisis Data

Teknik analisis yang digunakan dalam penelitian ini adalah deskriptif kuantitatif. Menurut (Suharsimi Arikunto., 1989), "Pada umumnya penelitian deskriptif merupakan penelitian non hipotesis sehingga dalam langkah penelitiannya tidak perlu merumuskan hipotesis". Penelitian dengan data kuantitatif memperoleh hasil perhitungan berupa angka-angka. (Suharsimi Arikunto., 1989) mengatakan, pengukuran data kuantitatif dapat dilakukan dengan beberapa cara : 
1. Dijumlahkan, dibandingkan dengan jumlah yang diharapkan dan diperoleh persentase. Dijumlahkan, diklasifikasikan sehingga merupakan suatu susunan urut data (arrai), untuk selanjutnya dibuat tabel, baik yang hanya berhenti sampai tabel saja, maupun yang diproses lebih lanjut menjadi perhitungan pengambilan kesimpulan ataupun untuk kepentingan visualisasi datanya.

2. Indikator Kinerja Penelitian, Tujuan yang akan dicapai dalam penelitian ini adalah meningkatnya hasil belajar gerak dasar Lompat jauh gaya menggantung siswa Kelas VI SDN Kanung 02 Kecamatan Sawahan Kabupaten Madiun Tahun Pelajaran 2019/2020. Setiap tindakan upaya pencapaian tujuan tersebut dirancang dalam satu unit sebagai satu siklus. Setiap siklus terdiri atas empat tahap, yaitu: (1) perencanaan tindakan, (2) pelaksanaan tindakan, (3) observasi dan interpretasi, dan (4) analisis dan refleksi untuk perencanaan siklus berikutnya.

\section{Hasil dan Pembahasan}

\section{Pengertian Lompat Jauh}

Lompat jauh adalah salah satu nomor lompat dalam cabang olahraga atletik. Lompat jauh merupakan suatu bentuk gerakan melompat mengangkat kaki ke atas ke depan dalam upaya membawa titik berat badan selama mungkin di udara (melayang di udara) yang dilakukan dengan cepat dengan jalan melakukan tolakan satu kaki untuk mencapai jarak sejauh-jauhnya. Dalam lompat jauh terdapat tiga macam gaya yaitu gaya jongkok, gaya menggantung dan gaya berjalan di udara (Prasetyo, 2016).

Lompat jauh gaya jongkok disebut juga gaya duduk di udara (sit down in the air). Dikatakan gaya jongkok karena gerakan yang dilakukan pada saat di udara membentuk seperti orang jongkok atau duduk. Gerakan jongkok atau duduk ini terlihat seperti membungkukkan badan dan kedua lutut ditekuk, kedua tangan di depan. Pada saat mendarat kedua kaki dijulurkan ke depan, mendarat dengan bagian tumit lebih dahulu dan kedua tangan ke depan. Untuk menghindari kesalahan saat mendarat, maka diikuti dengan menjatuhkan badan ke depan (Choirudin, 2012).

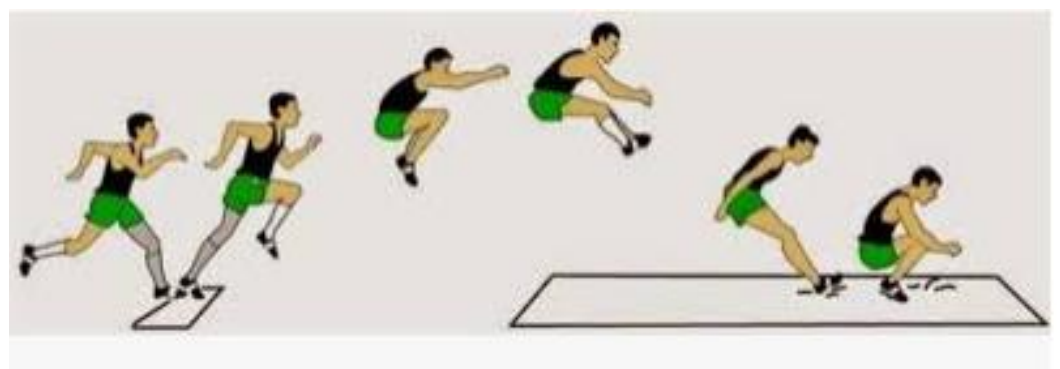

Gambar 1

Lompat jauh gaya menggantung

(Gilang, 2007)

Lompat jauh gaya menggantung merupakan gaya yang paling mudah dilakukan terutama bagi anak-anak sekolah. (Syarifudin, 1992) menyatakan bahwa, "lompat jauh gaya menggantung, pada umumnya banyak dilakukan anak-anak sekolah, 
karena dianggap gaya yang paling mudah untuk dipelajari”. Hal ini disebabkan karena lompat jauh gaya menggantung tidak banyak gerakan yang harus dilakukan pada saat melayang di udara dibandingkan dengan gaya yang lainnya. Konsentrasi atlet yang perlu diperhatikan pada gaya menggantung terletak pada membungkukkan badan dan menekuk kedua lutut dan menjulurkan kedua kaki ke depan dan kedua lengan tetap ke depan untuk mendarat.

\section{Teknik Lompat Jauh Gaya menggantung}

Teknik Lompat jauh gaya menggantung, Teknik merupakan rangkuman metode yang dipergunakan dalam melakukan gerakan dalam suatu cabang olahraga. Teknik ini juga merupakan suatu proses gerakan dan pembuktian dalam suatu cabang olahraga, atau dengan kata lain teknik merupakan pelaksanaan suatu kegiatan secara efektif dan rasional yang memungkinkan suatu hasil yang optimal dalam latihan atau perlombaan. Teknik lompat jauh terdiri beberapa bagian yang pelaksanaannya harus dirangkaikan secara baik dan harmonis (Prasetyo, 2016). (Muharram, 2015) menyatakan bahwa, "faktor-faktor yang sangat menentukan untuk mencapai prestasi dalam lompat jauh adalah awalan, tumpuan, lompatan, saat melayang, dan pendaratan". Untuk lebih jelasnya teknik lompat jauh dapat diuraikan sebagai berikut:

a. Awalan

Awalan merupakan tahap pertama dalam lompat jauh. Tujuan awalan adalah untuk mendapatkan kecepatan maksimal pada saat akan melompat dan membawa pelompat pada posisi yang optimal untuk tolakan. Awalan yang benar merupakan prasyarat yang harus dipenuhi, untuk menghasilkan jarak lompatan yang sejauhjauhnya. Pelompat harus berlari semakin cepat sehingga mencapai kecepatan penuh pada saat sebelum salah satu kaki menumpu. Adapun pelaksanaan awalan lompat jauh menurut (Aip Syarifudin, 1992) yaitu :

1. Jarak awalan tergantung pada tiap-tiap pelari (sekitar 30 sampai 40 meter). Jarak awalan harus cukup jauh dan lari cepat untuk mendapatkan momentum yang paling besar.

2. Kecepatan awalan dan irama langkah harus tetap. Pada saat melangkah konsentrasi tertuju pada lompatan yang setinggi-tingginya.

3. Langkah terakhir agak diperpendak, supaya dapat menolak ke alas dengan sempurna.

4. Sikap lari seperti pada lari jarak pendek.

5. Awalan lompat jauh harus dilakukan dengan harmonis, lancar dan dengan kecepatan tinggi, tanpa ada gangguan langkah yang diperkecil atau diperlebar untuk memperoleh ketepatan bertumpu pada balok tumpuan. (Aip Syarifudin, 1992) menyatakan bahwa "untuk menjaga kemungkinan pada waktu melakukan awalan itu tidak cocok, atau ketidak tepatan awalan dan tolakan, biasanya pelombat membuat dua buah tanda (cherkmark) antara permulaan akan memulai permulaan awalan dengan papan tolakan". 


\section{b. Tumpuan atau Tolakan (Take-Off)}

Tumpuan adalah salah satu tahap vital dalam rangkaian gerakan lompat jauh, hal yang perlu diperhatikan dalam melakukan tumpuan adalah penggunaan kaki terkuat agar tolakan yang dihasilkan dapat maksimal, selain itu perubahan arah gerakan juga harus diperhatikan, yaitu perubahan dari gerak lari kearah depan dilanjutkan tolakan keatas sehingga gerakan yang dihasilkan berbentuk parabola. Menurut (Aip Syarifudin, 1992) "tolakan adalah perubahan atau perpindahan gerakan dari gerakan horizontal ke gerakan vertikal yang dilakukan secara cepat". Tumpuan dilakukan dengan cara yaitu, sebelumnya pelompat menyiapkan diri untuk melakukan tolakan sekuat-kuatnya pada langkah terakhir, sehingga seluruh tubuh terangkat keatas melayang di uadara.

(Riyadi, 1985) menyatakan teknik menumpu pada lompat jauh sebagai berikut:

1. Tolakan dilakukan dengan kaki yang terkuat.

2. Sesaat akan bertumpu sikap badan agak condong kebelakang (jangan berlebihan) untuk membantu timbulnya lambungan yang lebih baik (sekitar $45^{\circ}$ ).

3. Bertumpu sebaiknya tepat pada papan tumpuan.

4. Saat bertumpu kedua lengan ikut serta diayunkan ke depan atas. Pandangan ke depan atas (jangan melihat ke bawah).

5. Pada kaki ayun (kanan) diangkat ke depan setinggi pinggul dalam posisi lutut ditekuk

\section{Melayang di Udara (Action in The Air)}

Sikap dan gerakan badan di udara sangat erat kaitannya dengan kecepatan awalan dan kekuatan tolakan, kecepatan lari dan kekuatan tolakan akan menentukan seberapa lama kita mampu melayang diudara, semakin lama kita berada diudara akan semakin terlihat gaya yang dihasilkan dan akan semakin jauh jangkauan yang tercapai. Menurut (Soegito, 1992)“sikap saat melayang adalah sikap setelah gerakan lompatan dilakukan dan badan sudah terangkat tinggi ke atas". Karena pada waktu lepas dari papan tolak, badan si pelompat dipengaruhi oleh kekuatan yang disebut "daya penarik bumi". Daya penarik bumi ini bertitik tangkap pada suatu titik yang disebut titik berat badan yang letaknya kira-kira pada pinggang pelompat sedikit dibawah pusar agak ke belakang. Hal ini artinya, pada saat melayang di udara merupakan letak yang akan membedakan gaya dalam lompat jauh.

Adapun cara melakukan sikap badan di udara menurut (Aip Syarifudin, 1992) sebagi berikut:

1. Sesaat setelah menumpu, kaki tumpu segera diluruskan selurus-lurusnya.

2. Mengangkat pinggul ke muka atas.

3. Diusahakn selama mungkin saat berada di udara dengan cara menjaga keseimbangan dan persiapan pendaratan. 
4. Pada saat melayang di udara, kedua kaki sedikit ditekuk sehingga posisi badan berada dalam sikap jongkok.

5. Sikap tubuh saat melayang ditentukan oleh gaya lompat jauh yaitu: gaya jongkok (tuck style), gaya menggantung atau melenting (hang style) dan gaya berjalan di udara (walking in the air).

\section{c. Pendaratan}

Sikap mendarat pada lompat jauh baik gaya jongkok, gaya menggantung maupun gaya berjalan di uadara adalah sama. Pendaratan merupakan tahap terakhir dari rangkaian gerakan lompat jauh. Pendaratan merupakan prestasi yang dicapai dalam lompat jauh. Mendarat dengan sikap dan gerakan yang efisien merupakan kunci pokok yang harus dipahami oleh pelompat. (Aip Syarifudin, 1992) menyatakan bahwa:

Sikap mendarat pada lompat jauh, baik untuk lompat jauh gaya jongkok, gaya menggantung, maupun gaya jalan diudara adalah sama. yaitu : Pada waktu akan mendarat kaki dibawa kedepan, kedua tangan ke depan. Kemudian mendarat apda kedua tumit terlebih dahulu dan mengeper, dengan kedua lutut dibengkokkan (ditekuk), berat badan dibawa ke depan supaya tidak jatuh ke belakang, kepala ditundukkan, kedua tangan kedepan.

d. Alat Bantu Pembelajaran

Alat bantu merupakan alat-alat yang digunakan oleh pendidik dalam menyampaikan pembelajaran. Alat bantu berfungsi sebagai sarana peraga dalam pembelajaran, hal ini bertujuan untuk mempermudah pemahaman siswa. (Muharram, 2015) menyatakan, "Alat bantu pembelajaran adalah alat-alat yang digunakan oleh guru sebagai sarana untuk membantu pelaksanaan kegiatan mengajar". Menurut (Gino, Suwarni, \& Maryanto, 1998) berpendapat, "alat bantu pembelajaran adalah semua alat yang digunakan dalam proses belajar mengajar dengan maksud untuk menyampaikan pesan (informasi) pembelajaran dari sumber (guru maupun sumber lain) kepada penerima (siswa)".

Alat bantu disusun berdasarkan prinsip bahwa pengetahuan manusia diterima atau ditangkap melaui panca indera. Semakin banyak panca indera yang digunakan untuk menerima informasi maka semakin jelas pengertian yang diperoleh. Media yang dapat dilihat indera mata (media visual) sangat membantu proses belajar mengajar anak dalam memahami konsep berpikir abstrak.

e. Manfaat Alat Bantu Pembelajaran

Alat bantu mempunyai arti penting dalam kegiatan pembelajaran. Alat bantu dapat dijadikan sarana untuk menyampaikan materi pembelajaran kepada siswa. Selain itu, alat bantu akan mempermudah siswa dalam mempelajari materi pembelajaran. Lebih lanjut (Gino et al., 1998) menyatakan, "dengan menggunakan alat bantu mengajar atau media, pengajaran dapat menjadi lebih konkrit dan menarik sehingga mudah untuk dimengerti dan dipahami anak didik". Sedangkan (Sya'diyah, 2018) menyatakan: 
Ada beberapa fungsi penggunaan media atau alat dalam proses pembelajaran, diantaranya :

1. Menarik perhatian siswa

2. Membantu mempercepat pemahaman dalam proses pembelajaran

3. Memperjelas penyajian pesan agar tidak bersifat verbalitis (dalam bentuk kata-kata tertulis atau lisan)

4. Mengatasi keterbatasan ruang

5. Pembelajaran lebih komunikatif dan produktif

6. Waktu pembelajaran bisa dikondisikan

7. Menghilangkan kebosanan siswa dalam pembelajaran

8. Meningkatkan motivasi siswa dalam mempelajari sesuatu atau menimbulkan gairah belajar

9. Melayani gaya belajar siswa beraneka ragam.

10. Meningkatkan kadar keaktifan/keterlibatan siswa dalam kegiatan pembelajaran

Alat bantu atau media pembelajaran memiliki manfaat yang sangat luas dalam kegiatan belajar mengajar. Dengan menggunakan alat bantu yang baik dan tepat, maka akan mendukung pencapaian hasil belajar yang optimal. Oleh karena itu guru penjas harus mampu memanfaatkan berbagai macam alat bantu pembelajaran, jika dalam pembelajaran materi penjas banyak kendala. (Lutan \& Suherman, 2000) menyatakan, "Terbuka kesempatan guru pendidikan jasmani untuk membuat sendiri alat-alat sesuai dengan kebutuhan guna menyampaikan bahan pelajaran".

Dari beberapa pendapat tersebut dapat disimpulkan bahwa penggunaan alat bantu pembelajaran dapat membantu dalam menyampaikan pengertian-pengertian yang bersifat abstrak menjadi lebih konkrit dan lebih mudah dipahami siswa. Selain itu, seorang guru juga bisa membuat sendiri alat-alat sesuai dengan kebutuhan dan tujuan pembelajaran.

f. Syarat Alat Bantu Pembelajaran yang Baik

Suatu alat pembelajaran dapat dikatakan baik apabila mempunyai tujuan pendidika untuk: Mengubah pengetahuan/pengertian, pendapat dan konsepkonsep, Mengubah sikap dan persepsi, Menanamkan tingkah laku/kebiasaan yang baru. Selain itu, alat bantu harus efisien dalam penggunakannya, dalam waktu yang singkat dapat mencakup isi yang luas dan tempat yang diperlukan tidak terlalu luas. Penempatan alat bantu perlu diperhatikan ketepatannya agar dapat diamati oleh seluruh siswa. Efektif artinya memberikan hasil guru yang tinggi ditinjau dari segi pesannya dan kepentingan siswa yang sedang belajar. Sedangkan yang dimaksud dengan komunikatif ialah bahwa media tersebut mudah untuk dimengerti maksudnya.

g. Alat Bantu Berupa Kotak Kardus

Alat bantu bilah, kardus, adalah alat bantu yang dibuat dalam upaya meningkatkan hasil belajar lompat jauh gaya menggantung siswa kelas VI SDN 
Kanung 02 Kecamatan sawahan Kabupaten Madiun Tahun Pelajaran 2019/2020. Bilah terbuat dari bambu yang dipotong dengan ukuran panjang 1 meter dan lebar 5-10 cm. Alat bantu kardus yang digunakan dalam penelitian ini adalah kardus kosong dengan ukuran panjang $40 \mathrm{~cm}$, lebar $25 \mathrm{~cm}$ dan tinggi $20 \mathrm{~cm}$. Kemudian dikombinasikan dengan ban bekas sepeda yang digunakan dengan ukuran diameter lingkaran $60 \mathrm{~cm}$. Sedangkan bola gantung yaitu bola plastik yang kemudian digantung dibambu dengan menggunakan jaring bola Dalam menentukan alat bantu yang digunakan didasarkan pada syarat-syarat penggunaan alat bantu yang baik. Media pendidikan yang memenuhi syarat, Dinbakir (2009) menjelaskan tentang Kriteria Pemilihan Media

1. Sesuai dengan tujuan yang ingin dicapai.artinya media dipilih berdasarkan tujuan instruksional yang telah ditetapkan.

2. Tepat untuk mendukung isi pelajaran yang sifatnya fakta, konsep prinsip atau generalisasi.

3. Praktis, luwes dan bertahan.

4. Guru terampil menggunakannya.

5. Pengelompokan sasaran.media yang efektif untuk kelompok besar belum tentu sama dengan efektifnya jika digunakan untuk kelompok kecil.

6. Mutu teknis

7. Kondisi siswa (dari segi subjek belajar)

Alat batu dipilih karena dirasa sudah cukup memenuhi syarat sebagai alat bantu pembelajaran. Selain dapat dipikirkan dan mudah digunakan, alat bantu bilah, kardus, bola gantung, dan ban bekas juga mudah didapat dan ekonomis dalam pembiayaan, selain itu dalam penggunaannya, alat bantu tersebut bukan termasuk alat yang berbahaya untuk digunakan dalam pembelajaran.

\section{Kesimpulan}

Penelitian Tindakan Kelas yang dilaksanakan pada siswa kelas VI SDN Kanung 02 Kecamatan Sawahan Kabupaten Madiun Tahun Pelajaran 2019/2020 dilaksanakan dalam dua siklus. Setiap siklus terdiri atas empat tahapan, yaitu: (1) perencanaan, (2) pelaksanaan tindakan, (3) observasi dan interpretasi, dan (4) analisis dan refleksi. Berdasarkan analisis data yang telah dilakukan dan pembahasan yang telah diungkapkan, diperoleh simpulan sebagai berikut:

Penggunaan alat bantu pembelajaran (bilah bambu, kardus, bola gantung, dan ban bekas) berhasil meningkatkan hasil belajar lompat jauh gaya menggantung pada siswa kelas VI SDN Kanung 02 Kecamatan Sawahan Kabupaten Madiun Tahun Pelajaran 2019/2020. Dari hasil analisis yang diperoleh, menunjukkan adanya peningkatan yang signifikan antara pra siklus, siklus I, dan siklus II. Hasil belajar lompat jauh gaya jongkok pada pra siklus dalam kategori tuntas adalah 33,3\% atau 6 siswa, pada akhir siklus I menjadi 55,55\% atau 10 siswa, kemudian kembali terjadi peningkatan setelah diberikan tindakan pada siklus II menjadi $88,88 \%$ atau 16 siswa. 


\section{BIBLIOGRAFI}

Aip Syarifudin. (1992). Atletik. Jakarta: Depdikbud, Dirjendikti, Proyek Pembinaan Tenaga Kependidikan.

Bajuri, Puput Eka. (2016). Penerapan Alat Bantu Pembelajaran Untuk Meningkatkan Hasil Belajar Lompat Tinggi Gaya Straddle. Jurnal Sportif, 2(2).

Choirudin, Muchlis. (2012). Upaya peningkatan gerak dasar lompat Jauh gaya jongkok dengan menggunakan alat bantu pembelajaran pada siswa kelas iv sd negeri 04 bejen karanganyar tahun ajaran 2011/2012. Jurnal Skripsi.

Gilang, Moh. (2007). Pendidikan jasmani, olahraga, dan kesehatan. Bandung: Yudhistira.

Gino, H. J., Suwarni, Suripto, \& Maryanto, Sutijan. (1998). Belajar dan Pembelajaran II. Surakarta. UNS Press.

Indra, Johannes. (2018). Perbedaan Pengaruh Pembelajaran Kooperatif Dan Kemampuan Motorik Terhadap Hasil Gerak Dasar Lari.

Irianto, Tri. (2020). Olahraga Pendidikan.

Lestari, Dwi Puji, Indarwati, Indarwati, \& Putra, Yudha Wahyu. (2018). Perbedaan Pengaruh Pemberian Plyometric Depth Jump Dan Box To Jump Terhadap Peningkatan Power Otot Tungkai Pada Pemain Bola Voli Di Sma Negeri Kebakkramat. STIKES'Aisyiyah Surakarta.

Lutan, Rusli, \& Suherman, Adang. (2000). Perencanaan pembelajaran penjaskes. Jakarta: Depdikbud.

Muharram, N. U. R. Ahmad. (2015). Upaya Meningkatkan Hasil Belajar Gerak Dasar Lompat Jauh Dengan Menggunakanalat Bantu Tradisional. Nusantara of Research: Jurnal Hasil-Hasil Penelitian Universitas Nusantara PGRI Kediri, 2(1).

Prasetyo, Koko. (2016). Penerapan Pendekatan Bermain untuk Meningkatkan Hasil Belajar Lompat Jauh Gaya Jongkok Pada Siswa Kelas 5 Sekolah Dasar. Scholaria: Jurnal Pendidikan Dan Kebudayaan, 6(3), 196-205.

Rachman, Hari Amirullah. (2011). Keterlaksanaan Pendidikan Jasmani Dan Olahragadi Daerah Istimewa Yogyakarta. Jurnal Pendidikan Jasmani Indonesia, 8(1).

Refiater, Ucok Hasian. (2012). Hubungan Power Tungkai Dengan Hasil Lompat Tinggi. Jurnal Health and Sport, 5(03).

Riyadi, Tamsir. (1985). Petunjuk Atletik. Yogyakarta: FPOK Yogyakarta Tim Penjas (2006). Pendidikan Jasmani Untuk Kelas, 3. 
Soegito. (1992). Teori dan Praktek Atletik I. Surakarta: UNS Press.

Srijono Brotosuryo, Sunardi dan M. Furqon H. (1994). Perencanaan Pengajaran Pendidikan Jasmani dan Kesehatan. Jakarta.: Depdikbud. Direktorat Jenderal Pendidikan Dasar dan Menengah. Direktorat Pendidikan Guru dan Tenaga Tekhnis Bagian Proyek Penataran Guru Pendidikan Jasmani dan Kesehatan SD Setara D-II.

Suharsimi Arikunto. (1989). Prosedur Penelitian, Suatu Pendekatan Praktik. Jakarta: Rinneka Cipta.

Suherman, Adang. (2000). Dasar-dasar penjaskes. Jakarta: Depdikbud.

Sya'diyah, Fathimah. (2018). Perbandingan hasil belajar siswa yang menggunakan metode take and give dan metode word square pada mata pelajaran Pai: Penelitian di smp karya budi kelas VII A dan VII b. UIN Sunan Gunung Djati Bandung.

Syarifudin, Aip. (1992). Olahraga Pilihan Atletik. Jakarta: Dirjen Dikti.

Utama, A. M. Bandi. (2011). Pembentukan Karakter Anak Melalui Aktivitas BermainDalam Pendidikan Jasmani. Jurnal Pendidikan Jasmani Indonesia, 8(1).

Wahidin, Unang. (2017). Pendidikan Karakter Bagi Remaja. Edukasi Islami: Jurnal Pendidikan Islam, 2(03). 